\title{
Physical-mechanical characterization of two amazon woods coming from the second cutting cycle
}

\author{
BRUNO M. BALBONI ${ }^{1}$, TARCILA S. DA SILVA ${ }^{1}$, FERNANDO W.C. ANDRADE ${ }^{1}$, \\ LUCAS J.M. DE FREITAS ${ }^{2}$ and VICTOR H.P. MOUTINHO ${ }^{1}$ \\ ${ }^{1}$ Laboratório de Tecnologia da Madeira, Universidade Federal do Oeste do \\ Pará, Av. Vera Paz, s/n, 68035-110 Santarém, PA, Brazil \\ ${ }^{2}$ Embrapa Amazônia Oriental, Laboratório de Manejo e Conservação Florestal, Travessa Dr. \\ Enéas Pinheiro, s/n, Caixa Postal 48, Bairro Marco, 66095-100 Belém, PA, Brazil
}

Manuscript received on October 24, 2017; accepted for publication on April 17, 2018

\begin{abstract}
Due to changes in the Amazon forest dynamics after the first cutting cycle, non exploited species become dominant in the forest. The lack of technological knowledge makes it hard to commercialize these woods, making the understanding of their physical-mechanical properties a fundamental step to properly define their applications. This study aimed to characterize physically and mechanically the wood of Pseudopiptadenia psilostachya and Eschweilera ovata from the second cutting cycle of the Tapajós National Forest, intending to commercially promote and to identify usages for them, as well as to evaluate the viability of replacement of highly commercialized species. The tests were performed accordingly to the Brazilian standard NBR 7190. P. psilostachya, presented bulk density of $0.683 \mathrm{~g} . \mathrm{cm}^{-3}$, medium levels of shrinkage and anisotropy, as well as medium hardness $(7366 \mathrm{~N})$ and high strength on compression parallel to grain (71.63 MPa) and on static bending (103.9 MPa). It was generally superior to Euxylophora paraensis, but inferior when compared to Bagasssa guianensis and Apuleia leiocarpa, with possibilities to replace these three species. E. ovata, on the other hand, presented bulk density of $0.798 \mathrm{~g} . \mathrm{cm}^{-3}$, high shrinkage and anisotropy values, but high values for hardness $(12089 \mathrm{~N})$ and strength on compression parallel to grain $(68.67 \mathrm{MPa})$ and on static bending (127.1 MPa). This species exhibited, in general, similarities with Mezilaurus itauba, although it is a little inferior in relation to Hymenaea sp. and Astronium lecointei. Both species, P. psilostachya and E. ovata fit in the highest strength class described on the Brazilian Standard NBR7190, C60. By means of the results found, it was concluded that although the species studied were unknown, they presented timber with enough quality to replace some Amazon timber species widely commercialized on both national and international market.
\end{abstract}

Key words: bulk density, shrinkage, MOR, MOE, classes of resistance.

Correspondence to: Victor Hugo Pereira Moutinho

E-mail: victor.moutinho@ufopa.edu.br 


\section{INTRODUCTION}

The forest management with reduced impacts has shown itself to be a sustainable alternative for obtaining non-wood and wood products originated from native forests, with the objective of minimizing the impact on the forest by allowing the remaining trees, of a 30-year cutting cycle, as foreseen in the Brazilian legislation (Castro 2012). However, there are no studies in the literature about the quality of the wood of the species that are retained for the second cutting cycle.

The first studies on forest management with reduced impacts were performed in the end of the 1970's, in an area belonging to the Brazilian company of agricultural research - EMBRAPA, inside the Tapajós National Forest, located at Km 67 of the BR 163 highway. Pereira Junior et al. (2006) believe that the impact and dynamic studies conducted after the first cutting cycle showed that the regeneration and the recovery of the forest supports the proceeding of a second cutting cycle, which has occurred in the end of 2014, 35 years after the first cutting. On the other hand, Reis et al. (2010) have reported big changes in the floristic composition, due to the intensity of the first harvest, decreasing the quantity of commercial wood and increasing the dominance of species less known in the traditional market.

According to Oliveira et al. (2011), because of the traditional exploration and the lack of scientific studies about the characteristics of woods of the other species, the timber market became restrict to few well known species with a medium to long production cycle, which often makes the recovery of this material in the market unfeasible, leading to a shortage of the product and in some cases risk of extinction of the species.

There is a great diversity of species with high potential for timber production in the Brazilian tropical forests. Countless species from the Amazon rainforest have great wood volumes but are considered of low value or even commercially worthless because they are unknown to the market. Many of them have properties similar to well known and high valued species, turning out to be suitable to most commercial application. However, the deficient technological knowledge and the traditionalism hampers their utilization (Gonçalez and Gonçalvez 2001).

As the lack of knowledge about a specific wood is a barrier to its appropriate use, a better understanding about Amazon woods is required. In this way, the physical and mechanical properties of wood can subside an adequate use of the wood and valorize species that are unknown to the market, which helps the reduction of ecological pressure on traditional timber species.

The objective of this study is to perform the physical and mechanical characterization of the wood of two nontraditional Amazon species coming from the second cutting cycle of the Tapajós National Forest, identifying their potential utilization and which species with large harvest intensity and demand in the industry could be replaced by them.

\section{MATERIALS AND METHODS}

\section{AREA OF STUDY AND SPECIE SELECTION}

The study was conducted in an experimental area belonging to the Brazilian company of agricultural research (EMBRAPA - acronym in Portuguese), inside of the Tapajós National Forest, located at km 67 of the BR 163 highway, in the city of Belterra, state of Pará, Brazil.

The species selection was made according to Moutinho et al. (2016). It was realized a previous analysis of the forest commercial inventory in the area, considering the criteria of great abundance, frequency and dominance, restricting it to those whose wood have not been previously characterized for their technological properties in the literature. The chosen species were: "Fava-timborana" 
(Pseudopiptadenia psilostachya) and "Matá-matá" (Eschweilera ovata). The botanic identification was made by specialists of the "Oriental Amazon EMBRAPA”, by collecting botanic samples (exsiccates) during the continuous forest inventory and the harvesting, performed in the management area.

\section{COLLECTION OF MATERIAL}

Samples with $2.6 \mathrm{~m}$ in length were collected from the butt logs from five individuals of $E$. ovata and four individuals of $P$. psilostachya. At the log yard, using a mobile sawmill (Lucas Mill), wood logs were converted into battens of $70 \times 70 \times$ $1800 \mathrm{~mm}^{3}$ of dimension, respecting the orientation of the growth rings in the tangential direction and avoiding the presence of sapwood and juvenile wood in the samples. Then, the samples were taken to the carpentry shop at the Universidade Federal do Oeste do Pará, where they were made into test samples.

\section{WOOD'S PHYSICAL-MECHANICAL CHARACTERIZATION}

The physical properties analyzed were anhydrous density $\left(\rho_{0 \%}\right)$, bulk density $\left(\rho_{\text {bas }}\right)$ and density at $12 \%$ of humidity $\left(\rho_{12 \%}\right)$, tangential shrinkage $\left(\varepsilon_{\mathrm{s}, \mathrm{tg}}\right)$, radial shrinkage $\left(\varepsilon_{\mathrm{s}, \mathrm{rad}}\right)$ and volumetric shrinkage $\left(\varepsilon_{\mathrm{s}, \mathrm{vol}}\right)$, as well as the coefficient of anisotropy (CA). The tested mechanical properties were the modulus of rupture $\left(\mathrm{f}_{\mathrm{M}}\right)$, modulus of elasticity $\left(\mathrm{E}_{\mathrm{M} 0}\right)$ in static bending, strength on compression parallel to grain $\left(\mathrm{f}_{\mathrm{c} 0}\right)$, and Janka hardness parallel $\left(\mathrm{f}_{\mathrm{H} 0}\right)$ and perpendicular $\left(\mathrm{f}_{\mathrm{H} 90}\right)$ to grain.

All tests were performed according to the Brazilian Standard for Wood Structures, NBR 7190 (ABNT 1997). The characteristic value for strength on compression parallel to grain $\left(f_{\text {cok }}\right)$ was estimated using an equation provided by the NBR7190 Standard (ABNT 1997) and was used to fit both species in the classes of resistance from the same standard.

\section{STATISTICAL ANALYSIS}

The data that exhibited homogeneity of variances and normal distribution were submitted to the t-test at the level of $5 \%$ of significance for the comparison of the means. In case of non-compliance with the prerogatives of the t-test, the data (all physical properties besides coefficient of anisotropy) were analyzed with the non-parametric test of Mann-Whitney-Wilcoxon, with the same level of significance (Yau 2013). For the accomplishment of the analysis and the confection of the graphs, the software R was used (R Development Core Team 2017).

\section{RESULTS}

\section{PHYSICAL PROPERTIES}

P. psilostachya bulk density was in average $0.683 \mathrm{~g}$. $\mathrm{cm}^{-3}$, ranging from $0.603 \mathrm{~g} . \mathrm{cm}^{-3}$ to $0.818 \mathrm{~g} . \mathrm{cm}^{-3}$, and average density at $12 \%$ moisture content (MC) of $0.777 \mathrm{~g} . \mathrm{cm}^{-3}$, ranging from $0.671 \mathrm{~g} . \mathrm{cm}^{-3}$ to 0.973 g. $\mathrm{cm}^{-3}$, while $E$. ovata has showed bulk density of $0.798 \mathrm{~g} . \mathrm{cm}^{-3}$ in average, varying between 0.722 g. $\mathrm{cm}^{-3}$ to 0.878 g.cm ${ }^{-3}$ (Table I).

$P$. psilostachya presented radial shrinkage of $3.51 \%$, tangential shrinkage of $6.39 \%$, longitudinal shrinkage of $0.3 \%$ and volumetric shrinkage of $11.15 \%$. The coefficient of anisotropy, ratio between tangential and radial shrinkage, was of 1.91. For E. ovata, the tangential, radial, longitudinal and volumetric shrinkage were, respectively, $10.37 \%$, $4.37 \%, 0.08 \%$ and $16.86 \%$, with coefficient of anisotropy of 2.37 .

\section{WOOD MECHANICAL PROPERTIES}

The resistance to compression parallel to fibers on some samples of $E$. ovata showed very low values $(18.7 ; 21.03 ; 21.75 ; 26.7 \mathrm{MPa})$, as shown on Figure 1 , and high standard deviation (17.93), resulting on an average of 62.01 MPa. During the tests, some samples failed in the fibers direction, but they had 
TABLE I

Wood physical properties of $P$. psilostachya and $E$. ovata. Mean values followed by standard deviation, between parentheses, and letters representing the statistical group, where different letters in the same column indicate significant statistical difference between treatments.

\begin{tabular}{ccccccccc}
\hline Species & $\boldsymbol{\rho}_{\mathbf{0} \%}$ & $\begin{array}{c}\boldsymbol{\rho}_{\text {bas }} \\
\left(\mathbf{g . c m}^{-3}\right)\end{array}$ & $\boldsymbol{\rho}_{\mathbf{1 2} \%}$ & $\boldsymbol{\varepsilon}_{\mathrm{s}, \mathrm{g}}$ & $\begin{array}{c}\boldsymbol{\varepsilon}_{\mathrm{s}, \mathbf{r a d}} \\
(\%)\end{array}$ & $\boldsymbol{\varepsilon}_{\mathrm{s}, \text { vol }}$ & CA \\
\hline P. psilostachya & $\mathbf{0 . 7 5 8}$ & $\mathbf{0 . 6 8 3}$ & $\mathbf{0 . 7 7 7}$ & $\mathbf{6 . 3 9}$ & $\mathbf{3 . 5 1}$ & $\mathbf{1 1 . 1 5}$ & $\mathbf{1 . 9 1}$ \\
& $(0.06) \mathrm{b}$ & $(0.05) \mathrm{b}$ & $(0.07) \mathrm{b}$ & $(0.87) \mathrm{b}$ & $(0.93) \mathrm{b}$ & $(2.2) \mathrm{b}$ & $(0.42) \mathrm{b}$ \\
E. ovata & $\mathbf{0 . 9 3 9}$ & $\mathbf{0 . 7 9 8}$ & $\mathbf{0 . 9 8 2}$ & $\mathbf{1 0 . 3 4}$ & $\mathbf{4 . 6 4}$ & $\mathbf{1 7 . 1 2}$ & $\mathbf{2 . 2 8}$ & $(0.44) \mathrm{a}$ \\
\hline
\end{tabular}

$\rho_{0 \%}=$ anhydrous density; $\rho_{\text {bas }}=$ Basic density; $\rho_{12 \%}=$ bulk density at $12 \%$ of humidity; $\varepsilon_{\mathrm{s}, \mathrm{tg}}=$ tangential shrinkage; $\varepsilon_{\mathrm{s}, \mathrm{rad}}=$ radial shrinkage; $\varepsilon_{\mathrm{s}, \mathrm{vol}}=$ volumetric shrinkage; $\mathrm{CA}=$ coefficient of anisotropy.

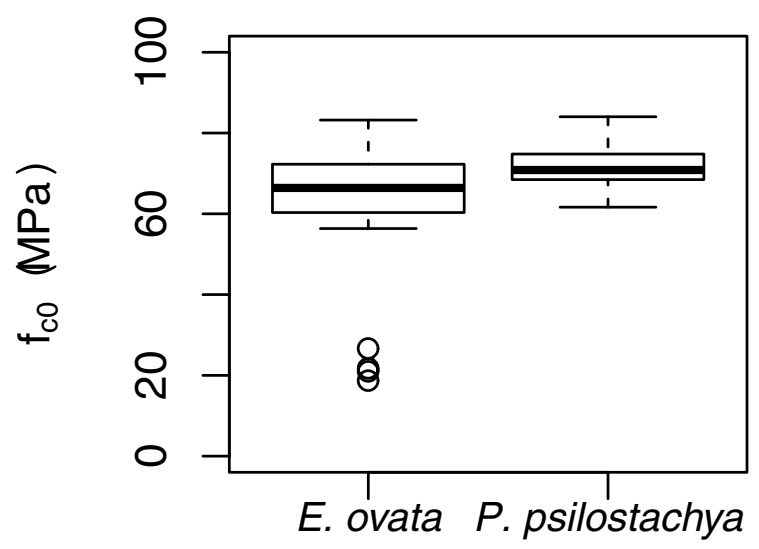

Figure 1 - Data distribution of resistance to parallel compression emphasizing the outliers on E. ovata.

not shown any external defects previously to the test; these samples exhibited very low resistance values. The cracks had probably been originated due to the difficulty of the wood to dry, even under mild conditions, as it is the case of an acclimatization room. Howsoever, as it is not the objective of this study to analyze that influence, those values were excluded from the analysis, returning the mean and standard deviation values shown on Table II for both species.

Table III compares the mechanical properties of species with similar density to the ones in this study. The values were taken from the literature. When necessary, the values of resistance and stiffness tested at $15 \% \mathrm{MC}$ were converted to $12 \%$ $\mathrm{MC}$, following the equations provided on NBR7190
(ABNT 1997). The missing values were either not shown in the original studies or were provided for green wood, thus not being convertible to $12 \% \mathrm{MC}$.

In comparison to woods of similar density (Table III), such as A. leiocarpa, B. guianensis and $E$. paraensis, $P$. psilostachya shows values of modulus of rupture in static bending 22 to $45 \%$ inferior to those species cited, yet its modulus of elasticity in static bending was between 18 to $25 \%$ superior to those described for the same species. Values of $\mathrm{f}_{\mathrm{c} 0}$ were $18 \%$ superior to those found for A. leiocarpa, and 5\% to E. paraensis, but $21 \%$ inferior to B. guianensis.

$E$. ovata had also demonstrated inferior mechanical properties when compared to species with similar density (Table III), with values of $\mathrm{f}_{\mathrm{M}} 23 \%$ inferior to $H$. stilbocarpa and $8 \%$ to $M$. itauba. Major differences were noticed in $\mathrm{f}_{\mathrm{c} 0}$, which was $30 \%, 25 \%$ and $17 \%$ inferior to the species cited above, respectively. Nevertheless, E. ovata's modulus of elasticity in static bending was $48 \%$ superior to M. itauba and $37 \%$ to A. lecointei.

\section{DISCUSSION}

Considering the average value of bulk density based on the Melo et al. (1992) classification criteria, $P$. psilostachya is considered a species of medium density. P. psilostachya's wood has similar values of bulk density to other commercial native 
TABLE II

Mechanical properties of wood of the studied species. Mean values followed by standard deviation, between parentheses, and letters representing the statistical group, where different letters in the same column indicate significant statistical difference between treatments.

\begin{tabular}{cccccc}
\hline \multirow{2}{*}{ Species } & $\mathbf{f}_{\mathbf{M}}$ & $\mathbf{E}_{\mathbf{M} \mathbf{0}}$ & $\mathbf{f}_{\mathbf{c} 0}$ & $\mathbf{f}_{\mathbf{H} \mathbf{0}}$ & $\mathbf{f}_{\mathbf{H}}$ \\
\cline { 2 - 6 } P. psilostachya & $\mathbf{1 0 3 . 9}(19.29)$ & $\mathbf{1 6 0 3 0}(219)$ & $\mathbf{7 1 . 6 3}(4.84)$ & $\mathbf{7 3 6 6}(1386)$ & $\mathbf{7 2 0 0}(1680)$ \\
& $\mathrm{b}$ & $\mathrm{b}$ & $\mathrm{a}$ & $\mathrm{b}$ & $\mathrm{b}$ \\
\hline \multirow{2}{*}{ E. ovata } & $\mathbf{1 2 7 . 1}(10.31)$ & $\mathbf{1 7 8 7 0}(265)$ & $\mathbf{6 8 . 6 7}(17.93)$ & $\mathbf{1 2 0 8 9}(1052)$ & $\mathbf{1 1 8 5 1}(921)$ \\
& $\mathrm{a}$ & $\mathrm{a}$ & $\mathrm{b}$ & $\mathrm{a}$ & $\mathrm{a}$ \\
\hline
\end{tabular}

$\mathrm{f}_{\mathrm{M}}=$ modulus of rupture in static bending; $\mathrm{E}_{\mathrm{M} 0}=$ modulus of elasticity in static bending; $\mathrm{f}_{\mathrm{c} 0}=$ resistance to parallel compression; $\mathrm{f}_{\mathrm{H} 90}$ $=$ Janka hardness normal to fibers; $\mathrm{f}_{\mathrm{H} 0}=$ Janka hardness parallel to fibers.

TABLE III

Mean values of physical and mechanical properties of woods with similar density values to those studied in this study. Source: Adapted from IBAMA (1997), IBDF (1981), IPT (1989) and Andrade (2015).

\begin{tabular}{|c|c|c|c|c|c|c|c|c|c|c|c|}
\hline \multirow[t]{2}{*}{ Scientific name } & \multirow{2}{*}{$\underset{\left(\mathrm{g} \cdot \mathrm{cm}^{-3}\right)}{\rho_{\text {bas }}}$} & $\varepsilon_{\mathrm{s}, \mathrm{tg}}$ & $\varepsilon_{\mathrm{s}, \mathrm{rad}}$ & $\varepsilon_{\mathrm{s}, \mathrm{vol}}$ & \multirow[t]{2}{*}{ CA } & $\mathbf{f}_{\mathrm{M}}$ & $\mathbf{E}_{\mathrm{M} 0}$ & $\mathbf{f}_{\mathrm{c} 0}$ & $\mathbf{f}_{\mathrm{H} 0}$ & $\mathbf{f}_{\mathrm{H} 90}$ & \multirow[t]{2}{*}{ Source } \\
\hline & & \multicolumn{3}{|c|}{$(\%)$} & & \multicolumn{3}{|c|}{ (MPa) } & \multicolumn{2}{|c|}{$(\mathrm{N})$} & \\
\hline Eschweilera sp. & 0.81 & 10.7 & 6.0 & 16.1 & 1.78 & 168.2 & 18926 & 86.4 & 14622 & 13622 & $\begin{array}{l}\text { IBDF } \\
(1988)\end{array}$ \\
\hline Mezilaurus itauba & 0.80 & 6.7 & 2.3 & 12.1 & 2.91 & 137.9 & - & 74.6 & - & - & $\begin{array}{c}\text { IPT } \\
(1989)\end{array}$ \\
\hline Mezilaurus itauba & 0.70 & 7.9 & 2.6 & 10.5 & 3.04 & 112.2 & 12062 & 57.2 & 5390 & 5792 & $\begin{array}{l}\text { IBDF } \\
(1981)\end{array}$ \\
\hline Hymenaea stilbocarpa & 0.80 & 7.2 & 3.1 & 10.7 & 2.32 & 165.5 & - & 89.6 & - & - & $\begin{array}{c}\text { IPT } \\
(1989)\end{array}$ \\
\hline Astronium lecointei & 0.81 & 6.3 & 3.3 & 11.2 & 1.91 & - & - & 82.4 & - & - & $\begin{array}{c}\text { IPT } \\
(1989)\end{array}$ \\
\hline Astronium lecointei & 0.79 & 7.6 & 4.6 & 11.9 & 1.65 & 102.2 & 12959 & 82.4 & - & - & $\begin{array}{c}\text { Andrade } \\
(2015)\end{array}$ \\
\hline Piptadenia suaveolens & 0.72 & 7.1 & 4.9 & 11.3 & 1.45 & 126.0 & 13141 & 68.4 & 7188 & 7698 & $\begin{array}{l}\text { IBDF } \\
(1981)\end{array}$ \\
\hline Piptadenia suaveolens & 0.76 & 9.1 & 5.4 & 15.1 & 1.68 & 146.9 & 13141 & 78.3 & 8806 & 9601 & $\begin{array}{c}\text { IBAMA } \\
(1997)\end{array}$ \\
\hline Piptadenia suaveolens & 0.76 & 8.3 & 5.1 & 13.1 & 1.63 & 105.8 & 15396 & 78.3 & 8800 & 9594 & $\begin{array}{l}\text { IBDF } \\
(1988)\end{array}$ \\
\hline Apuleia leiocarpa & 0.67 & 8.5 & 4.4 & 14.0 & 1.93 & 136.6 & - & 59.2 & - & - & $\begin{array}{c}\text { IPT } \\
(1989)\end{array}$ \\
\hline Bagassa guianensis & 0.68 & 7.1 & 5.5 & 11.4 & 1.29 & 150.6 & - & 86.9 & - & - & $\begin{array}{c}\text { IPT } \\
(1989)\end{array}$ \\
\hline Euxylophora paraensis & 0.69 & 8.5 & 7.0 & 15.1 & 1.22 & 126.9 & 13729 & 69.4 & 12435 & - & $\begin{array}{c}\text { IBAMA } \\
\text { (1997) }\end{array}$ \\
\hline
\end{tabular}


species from Amazon rainforest, such as Apuleia leiocarpa, $0.670 \mathrm{g.cm}^{-3}$, Bagassa guianensis 0.680 g.cm ${ }^{-3}$ and Euxylophora paraensis 0.690 g.cm ${ }^{-3}$ (IPT 1989). The results found for E. ovata in this study are similar to those reported in Moutinho (2008), that studying the same species, obtained values of 0.81 g.cm $\mathrm{cm}^{-3}$ for basic density, $8.72 \%$ for tangential shrinkage, $5.56 \%$ for radial shrinkage and $14.39 \%$ for volumetric shrinkage.

When compared to those species with similar basic density cited above, P. psilostachya has demonstrated smaller shrinkage in all cases, although the coefficient of anisotropy was greater than in E. paraensis, 1.2, and in B. guianensis, 1.29, but less than in A. leiocarpa, 1.93 (IPT 1989). In its turn, E. ovata's bulk density has demonstrated similarities to Astronium lecontei with bulk density

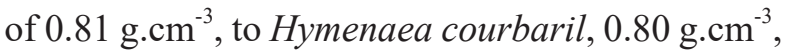
and to Mezilaurus itauba, $0.80 \mathrm{~g} . \mathrm{cm}^{-3}$ (IPT 1989), being the four of them considered of high density, according to Melo et al. (1992).

The values of shrinkage for P. psilostachya are consistent with what was reported in the literature for Piptadenia suaveolens, which was the botanic classification for P. psilostachya in the time of the study (EMBRAPA Amazônia Oriental 2004). The only exception is the coefficient of anisotropy, which is 15 to $25 \%$ greater, mainly because of the lower values of radial contraction. It is important to cite that softwoods, represented in Brazil mainly by species of the genus Pinus, are recognized for their low shrinkage, which makes them an excellent comparison of parameters. Although Pinus elliottii has low bulk density $\left(0.4 \mathrm{~g} . \mathrm{cm}^{-3}\right)$, its shrinkage properties described by IPT (1989), 3.4\%, 6.3\% and $10.5 \%$ for radial, tangential and volumetric contractions, respectively, are virtually identical to the ones found for P. psilostachya. Thereby, it can be said that $P$. psilostachya presents low shrinkage values.

Gonçalez et al. (2006), affirm that the dimensional stability of wood and its derivative products has the shrinkage amplitude as a good indicator, and the coefficient of anisotropy clarifies the deformations that occur during wood drying, being considered an important criteria for judging the quality of wood and its further utilization. According to Durlo and Marchiori (1992) the values ranging from 1.5 to 2.0 for the CA characterizes wood as being of medium dimensional stability, which is the case for P. psilostachya.

It was also compared E. ovata shrinkage to those species mentioned above with similar density. E. ovata has higher linear and volumetric shrinkages when compared to Astronium leicontei, Hymenaea courbari land Mezilaurus itauba (Table III). However, the coefficient of anisotropy is only superior to A. lecointei. The values described for Eschweilera sp. by Moutinho (2008) are consistent to those presented in this study, even though a smaller coefficient of anisotropy was noticed, which, is believed, was due to a greater radial shrinkage.

Different from P. psilostachya, E. ovata wood showed higher values of shrinkage, approaching those reported for species of Eucalyptus, known for their high shrinkage level. Scanavaca Junior and Garcia (2004) found values of tangential, radial, longitudinal and volumetric shrinkage of $12.5 \%$, $7.2 \%, 0.11 \%$ and $19,8 \%$, respectively, for various sources of Eucalyptus urophylla. According to Vermaas (1995), a high shrinkage value, associated with low permeability, is one of the factors that makes species of Eucalyptus so difficult to dry without producing defects. E. ovata, due to its high density, has a tendency of presenting low permeability and high incidence of shrinkages, therefore being prone to present defects during the drying process.

The coefficient of anisotropy is also a characteristic that makes wood susceptible to present drying defects. As E. ovata presented CA of 2.28 , the species is classified as of low quality 
regarding this characteristic (Durlo and Marchiori 1992).

The results found for the mechanical properties of $P$. psilostachya are inferior to those found to $E$. ovata, except for compression parallel to fibers. These results can be justified due to the fact that P. psilostachya's wood has low density. However, it was expected that the resistance to compression parallel to fibers would follow the same pattern, and also present itself inferior to E. ovata. It turns out to be possible that problems related to the wood drying process, which had resulted from the exclusion of outliers, has influenced, even if in small degree, the resistance to compression in E. ovata as a whole, but not to the point of being visually observable after the tests.

In general, it is realized that although both studied species present less resistance to those with similar density, they have superior hardness.

P. psilostachya did not show adequate characteristics to be used for wooden floors, since its Janka hardness fits in the lowest classification level of the Sustainable Wood Floor Design Project - ITTO (Andrade 2015). On the other hand, E. ovata has been classified as a threshold between the first and second classes of the same classification, being in that way a potential species to be used for wooden floors.

Piptadenia suaveolens, one of the botanic synonyms for $P$. psilostachya (EMBRAPA Amazônia Oriental 2004), is in accordance with IBDF (1998), indicated for uses in civil construction, furniture frame, boards, music instruments and boats.

No studies about the mechanical properties of Eschweilera ovata wood were found in the literature. However, other species of the same genus have been described. Eschweilera sp., for example, is indicated for civil construction and E. amara for carpentry, wood toys and household goods (IBDF 1988).
Based on the physical and mechanical properties of E. ovata's wood and on its comparison with already known commercial species for many uses, it is possible to indicate the species for civil construction, furniture and wooden floors.

The indication of both woods, $P$. psilostachya and E. ovata, for external uses, is only possible after performing durability tests.

The characteristic value in parallel compression have met the stipulated requirements of the standard, and the calculated values were $71.68 \mathrm{MPa}$ for P. psilostachya and $63.83 \mathrm{MPa}$ for E. ovata. P. psilostachya fits in the class $\mathrm{C} 60$, although its values of $\rho_{12 \%}$ are lower than the standard description for the class $\left(1.0 \mathrm{~g} . \mathrm{cm}^{-3}\right)$. E. ovata was classified in the same class as $P$. psilostachya (C60), with density value similar to the described for this class.

Although, in general, P. psilostachya and E. ovata had shown inferior mechanical properties to woods with similar density, both species fit in the class with greater resistance, $\mathrm{C} 60$, and therefore have a high potential for use.

\section{CONCLUSION}

Pseudopiptadenia psilostachya wood presented medium bulk density, medium value of shrinkage and high mechanical resistance, being able to be used in civil construction and decoration; it could replace species such as Bagassa guianensis, Apuleia leiocarpa and Euxylophora paraensis.

Eschweilera ovata wood presented high density bulk, with high coefficient of anisotropy and high mechanical resistance, proving to be appropriate for uses such as large wooden structures, civil construction, decoration, and general utilization; it can be used for replacing species like Astronium lecontei, Mezilaurus itauba and Hymenaea sp.

Both species are graded in the class of greater resistance (C60), according to Brazilian standard NBR7190. 


\section{ACKNOWLEDGMENTS}

To the Instituto Chico Mendes de Conservação da Biodiversidade (ICMBio), to the Empresa Brasileira de Pesquisa Agropecuária (EMPRAPA), to the Universidade Federal do Oeste do Pará (UFOPA), to the Cooperativa Mista da Floresta Nacional do Tapajós (COOMFLONA), to the Laboratório de Tecnologia da Madeira (LTM) of UFOPA, and to Conselho Nacional de Desenvolvimento Científico e Tecnológico (CNPq) for the project funding.

\section{REFERENCES}

ANDRADE A. 2015. Pisos de madeira: características de espécies brasileiras. Piracicaba: ANPM, 184 p.

ABNT - ASSOCIAÇÃO BRASILEIRA DE NORMAS TÉCNICAS. 1997. Projetos de estruturas de madeira NBR 7190. Rio de Janeiro, 107 p.

CASTRO TN. 2012. Comparação de diferentes formas de colheita florestal na Amazônia brasileira através da modelagem da produção e do crescimento, $72 \mathrm{p}$. Dissertação de Mestrado. Universidade de São Paulo, Piracicaba. (Unpublished).

DURLO MA AND MARCHIORI JNC. 1992. Tecnologia da madeira: retratibilidade. Santa Maria: CEPEF/FATEC, 33 p. (Série Técnica, 10).

EMBRAPA AMAZÔNIA ORIENTAL. 2004. Espécies Arbóreas da Amazônia. n. 9: Timborana, Pseudopiptadenia psilostachya.

GONÇALEZ JC, BREDAL CS, BARROS JFM, GONÇALVEZ DM, JANIN G, COSTA AF AND VALE AT. 2006. Características tecnológicas das madeiras de Eucalyptus grandis W. Hille x Maidene Eucalyptus cloeziana F. Muell visando ao seu aproveitamento na indústria moveleira. Ciênc Florest 16(3): 329-341.

GONÇALEZ JC AND GONÇALVEZ DM. 2001. Valorização de duas espécies de madeira Cedrelinga catenaeformis e Enterolobium shomburgkii para a indústria madeireira. Brasil Florestal 71: 69-74.

IB DF - INSTITUTO BRASILEIRO DE DESENVOLVIMENTO FLORESTAL. 1981. Madeiras da Amazônia: Características e utilização; Floresta Nacional do Tapajós. Brasília CNPq, v. 1, 113 p.

IBAMA - INSTITUTO BRASILEIRO DO MEIO AMBIENTE E DOS RECURSOS NATURAIS RENOVÁVEIS. 1997.
Madeiras Tropicais Brasileiras. Brasília: IBAMA/LPF, $152 \mathrm{p}$.

IPT - INSTITUTO DE PESQUISAS TECNOLÓGICAS DO ESTADO DE SÃO PAULO. 1989. Fichas de Características das Madeiras Brasileiras, $2^{\mathrm{a}}$ ed., São Paulo: IPT, $418 \mathrm{p}$.

MOUTINHO VHP. 2008. Caracterização das madeiras conhecidas na Amazônia como matá-matá. (Lecythidaceae fam. A. Rich.), 78 p. Dissertação de Mestrado. Universidade Federal de Lavras, Lavras. (Unpublished).

MOUTINHO VHP, ROCHAJJM, AMARAL EPC, SANATAN LGM AND AGUIAR OJR. 2016. Chemical and energetic properties of Amazonian woods of the second cutting cycle. Floresta Ambient 3(1): 443-449.

MELO JE, CORADIN VTR AND MENDES JC. 1992. Classes de densidade de madeira para a Amazônia brasileira. Silvicultura, São Paulo 12(42): 695-699.

OLIVEIRA LM, SOUSA LKV, MOUTINHO VHP, SILVA UCS, AGUIAR JOR, CARVALHO JOP AND MELO MS. 2011. Estudo fitossociológico e tecnológico de novas espécies madeireiras em três áreas de manejo florestal sustentável em assentamentos agrários na região de Santarém, PA, 143 p. Relatório técnico, CNPq. (Unpublished).

PEREIRA JÚNIOR RA, MARTINS DP AND PEREIRA DC. 2006. Práticas de manejo e exploração florestal no âmbito do projeto Tapajós. In: Pereira Junior RA (Org), Floresta Nacional do Tapajós: experiências e lições para implementação do manejo florestal em Unidades de Conservação. Belém: Projeto Tapajós, p. 35-92.

REIS LP, RUSCHEL AR, COELHO AA, LUZ AS AND MARTINS-DA-SILVA RCV. 2010. Avaliação do potencial madeireiro na Floresta Nacional do Tapajós, após 28 anos da exploração florestal. PFB 30(64): 265-281.

SCANAVACA JUNIOR L AND GARCIA JN. 2004. Determinação das propriedades físicas e mecânicas da madeira de Eucalyptus urophylla. Sci For 65: 120-129.

R DEVELOPMENT CORE TEAM. 2017. R: A Language and Environment for Statistical Computing. R Foundation for Statistical Computing, Vienna, Austria. Available at: http:// www.r-project.org.

VERMAAS HF. 1995. Drying Eucalypts for Quality: Material Characteristics, Pre-Drying Treatments, Drying Methods, Schedules and Optimization of Drying Quality. South African Forestry Journal 174(1): 119-132.

YAUC. 2013. R-Tutorial: An R Introduction to Statistics. Amazon Digital Services, $554 \mathrm{p}$. 